\title{
Kampung literasi dalam potret masyarakat Desa Maredan Barat Kecamatan Tualang Kabupaten Siak
}

\author{
Hadriana, Mahdum, M. Jaya Adi Putra, \& Daeng Ayub Natuna \\ Universitas Riau \\ * hadriana@lecturer.unri.ac.id
}

\begin{abstract}
Abstrak. Kampung Literasi merupakan kawasan kampung yang digunakan untuk mewujudkan masyarakat yang memiliki pengetahuan dan pemahaman yang luas yang sekaligus merupakan sebuah program untuk mewujudkan Sustainable Development Goals pada tahun 2030. Upaya penting yang dilakukan sebagai langkah awal untuk membangun Kampung Literasi di Desa Maredan Barat secara fisik adalah membangun sebuah Taman Bacaan Masyarakat, sekaligus membangun persepsi positif masyarakat terhadap Kampung Literasi. Tulisan ini akan menjelaskan tentang usaha yang dilakukan dalam membangun Kampung Literasi tersebut. Untuk mendapatkan umpan balik dan persepsi masyarakat tentang Kampung Literasi, 56 orang responden diminta untuk memberikan respon terhadap angket yang diberikan. Responden dipilih secara stratified random sampling. Hasil analisis angket memperlihatkan bahwa masyarakat memiliki persepsi yang positif terhadap pengembangan Kampung Literasi. Kegiatan pembangunan Kampung Literasi secara umum dapat dikatakan berhasil, walaupun masih terdapat kendala-kendala disebapkan adanya pandemi Covid-19.
\end{abstract}

Kata kunci: kampung literasi, masyarakat, Maredan Barat

Abstract. Literacy Village is a village area that is used to create people who have broad knowledge and understanding. At the same time, it is also a program to realize the Sustainable Development Goals in 2030. An important effort made as the first step to build a Literacy Village in Maredan Barat physically is to build a Community Reading Park, as well as building positive perceptions of the community towards Literacy Village. This paper will explain the efforts made in building this Literacy Village. To get feedback and people's perceptions about the activities done, 56 respondents were asked to give their responce to the given questionnaire. Respondents were selected by stratified random sampling. The results of the questionnaire analysis show that the community has a positive perception of the development of Literacy Village. In general, activities of Literacy Village development can be said to be successful, although there are still obstacles due to the Covid-19 pandemic.

Keywords: literacy village, community, Maredan Barat

To cite this article: Hadriana., Mahdum., M. J. A. Putra., \& D. A. Natuna. 2020. Kampung literasi dalam potret masyarakat Desa Maredan Barat Kecamatan Tualang Kabupaten Siak. Unri Conference Series: Community Engagement 2: 506--513. https://doi.org/10.31258/unricsce.2.506-513

(C) 2020 Authors

Peer-review under responsibility of the organizing committee of Seminar Nasional Pemberdayaan Masyarakat 2020 


\section{PENDAHULUAN}

Data minat baca dan tingkat buta aksara disebut-sebut berpengaruh terhadap posisi Human Development Index (HDI) Indonesia. HDI berkaitan dengan Indeks Pembangunan Manusia (IPM) yang diukur dari usia harapan hidup (tingkat kesehatan), pertumbuhan ekonomi dan kualitas pendidikan. Data yang dirilis United Nations Development Program (UNDP), HDI Indonesia di tahun 2013 berada di peringkat ke-108 dari 187 negara dengan nilai 68,40 dan naik tipis menjadi 68,90 pada tahun 2014. Angka HDI ini menunjukkan bahwa Indonesia juga berada jauh di bawah sejumlah negara di ASEAN (Kementerian Pendidikan dan Kebudayaan, 2017).

Litarasi adalah salah satu dari Tujuan Pembangunan Berkelanjutan (Sustainable development goals/ SDGs) yang ditetapkan pada tahun 2015 hingga Resolusi 70/1 dari Sidang Umum Perserikatan Bangsa-Bangsa (Purwanti, Ispriyarso, \& Wijaningsih, 2018). Artinya, literasi bukan saja amanat dari permasalahan Indonesia, tetapi menjadi amanat dunia untuk mengembangkan pembanaunan Dunia. Literasi merupakan kemampuan seseorang dalam mencari, mengoleksi, mengevaluasi atau menginterpretasikan, menggunakan, dan mengkomunikasikan informasi dari berbagai sumber secara tepat dan efektif. Artinya literasi menjauhkan seseorang dari kebodohan, karena di saat mempunyai suatu masalah masyarakat tahu di mana harus mencari informasi pemecahan masalahnya. Oleh karenanya, rendahnya minat baca sangat berpengaruh kepada literasi masyarakat. Lebih jauh, sehebat apa pun perpustakaan yang dimiliki, tidak bisa berbuat banyak jika masyarakatnya tidak senang membaca.

Sebagai upaya membangun wawasan masyarakat, perlu ada wadah bersama yaitu Kampung Literasi. Kampung Literasi adalah wilayah kampung yang digunakan untuk mewujudkan masyarakat yang memiliki pengetahuan dan pemahaman yang luas. Kampung Literasi memiliki serangkaian kegiatan yang berkesinambungan sebagai upaya untuk menjaga agar kegiatan literasi di masyarakat terus berkelanjutan. Salah satu harapan dari kegiatan kampung literasi adalah menjadi tempat lahir dan tumbuhnya simpul-simpul masyarakat yang literat, yang pada akhirnya sejahtera secara wawasan dan juga ekonomi (Kementerian Pendidikan dan Kebudayaan, 2017).

Prinsip dasar dalam pembentukan Kampung Literasi adalah "dari, oleh dan untuk masyarakat" (Hidayah, Widodo, \& Sueb, 2019) . Tonggak keberhasilannya adalah tersedianya taman bacaan masyarakat, pojok baca, ataupun perpustakaan desa. Masyarakat memiliki pengetahuan, keterampilan dan pengembangan sikap yang positif sehingga memiliki kualitas hidup yang baik (Hayati \& Suryono, 2015). Serta tersedianya sarana sumber akses informasi kepada masyarakat yang berkaitan dengan enam komponen literasi, yaitu literasi baca tulis, literasi berhitung, literasi sains, literasi teknologi informasi dan komunikasi (TIK), literasi keuangan serta literasi budaya dan kewarganegaraan (Kementerian Pendidikan dan Kebudayaan, 2017).

Jika melihat melihat persyaratan yang tertuang dalam panduan penyelenggaraan Kampung Literasi, maka agak sulit bagi desa Desa Maredan Barat untuk mendapatkan predikat sebagai sebuah kampung yang memiliki persyaratan yang ditetapkan pemerintah. Namun, sebagai langkah awal Desa Maredan Barat memiliki sebuah ruang pertemuan yang dimasa yang akan datang dapat dijadikan sebuah Taman Bacaan Masyarakat (TBM). Adanya TBM akan dapat dijadikan tahap permulaan didirikannya Kampung Literasi di desa Maredan Barat Kecamatan Tualang Kabupaten Siak. Berkat dukungan penuh dari kepala desa, yang bersedia memberikan beberapa ruang pertemuan yang bisa di fungsikan sesuai ruang baca dan ruang pertemuan, Desa Maredan Barat memiliki standar yang dipandang layak untuk dijadikan rintisan Kampung Literasi.

Desa Maredan Barat merupakan sebuah desa dengan luas wilayah 383,07 km2, yang terdiri dari 2 Dusun, 12 RT, dan 4 RW. Berdasarkan data kependudukan tahun 2018, jumlah penduduk di Kampung Maredan Barat adalah sebesar 2.715 jiwa. Desa Maredan Barat memiliki banyak lahan kosong yang masih bisa dikelola. Selain itu desa ini mempunyai dataran yang tinggi dan struktur lahan yang berbukit dan bergelombang, sehingga kebanyakan lahan yang ada di Desa Maredan Barat didominasi tanaman kelapa sawit. Keadaan perekonomian masyarakat di desa Maridan Barat didukung oleh Usaha Ekonomi Desa Simpan Pinjam (UED-SP) Maredan yang didirikan berdasarkan hasil musyawarah desa pada tanggal 10 Juni 2011. Sedangkan bila ditinjau dari tingkat pendidikan, klasifikasi tingkat pendidikan penduduk yang berada pada usia sekolah pada tahun 2020 adalah adalah sebagai berikut: 
Tabel 1: Klasifikasi Penduduk Berdasarkan Tingkat Pendidikan

\begin{tabular}{clc}
\hline No & \multicolumn{1}{c}{ Tingkat Pendidikan } & Jumlah \\
\hline 1 & Tamat SD/ sederajat & 781 \\
2 & Tamat SMP/ sederajat & 549 \\
3 & Tamat SMA/ sederajat & 273 \\
4 & Tamatan S1 & 17 \\
5 & Sedang mengikuti S1 & 24 \\
\hline
\end{tabular}

Sumber: Kantor Kepala Desa Maredan Barat

Dari Tabel 1 terlihat bahwa mayoritas penduduk masih berada pada tingkatan sekolah dasar dan menengah. Masih kecil sekali jumlah penduduk yang duduk di bangku kuliah maupun yang sudah mendapat gelar sarjana.

Berdasarkan survei lapangan dan wawancara dengan kepala desa Maredan Barat terungkap beberapa hal yang menjadi kendala bagi pembangunan desa ini antara lain: (1) Belum adanya konsep/model pembangunan desa yang dapat menjadi solusi secara optimal dalam upaya pengentasan kemiskinan. (2) Sumber daya manusia di Maredan Barat ini, baik aparat maupun masyarakatnya, memberikan kontribusi besar terhadap melambatnya berbagai upaya pelaksanaan pembangunan desa. (3) Keterbatasan sumber pendanaan, baik yang bersumber dari desa maupun dari kabupaten, provinsi dan nasional, merupakan faktor utama lain yang menyebabkan lambatnya proses pembangunan. Disisi lain anggaran yang disediakan/dialokasikan untuk desa, baik dari kabupaten, provinsi maupun dari nasional, cenderung bersifat project (pekerjaan khusus yang punya jangka waktu), bahkan charity (amal/kebaikan hati), bersifat sesaat dan berdampak pada golongan tertentu saja.

Sebagian besar kawasan desa Maredan Barat ditanami dengan tanaman kelapa sawit dan tanaman karet dengan kondisi lahan bergambut, tidak heran bila kedua sektor inilah yang mengerakkan perekonomian rakyat. Namun, petani sawit di desa Maredan Barat masih merupakan petani sawit yang tradisional yang belum mampu memanfaatkan limbah pelepah sawit secara baik dan optimal. Padahal, pohon sawit memiliki karakter yang hampir sama dengan pohon kelapa. Hampir semua bagian pohon sawit dapat dimanfaatkan untuk dijadikan produk bernilai ekonomi. Idealnya, para petani juga perlu meremajakan kembali kelapa sawit yang sudah tua. Syahza (2018) mengatakan petani sebagai pemilik perkebunan kelapa sawit merupakan faktor kunci keberhasilan dalam penanaman kembali kelapa sawit. Lebih jauh Syahza mengatakan bahwa petani kelapa sawit perlu dibina dan diberi pengetahuan kewirausahaan karena diantara karakteristik petani yang sukses adalah mereka yang berorientasi kewirausahaan, diantaranya: inovatif, percaya diri, dan kooperatif. Salah satu cara untuk menumbuhkan kecakapan berwirausaha di kalangan masyarakat adalah dengan meningkatkan kemampuan kewirausahaan yang berbasis teknologi atau yang lazim dikenal sebagai technopreneurship (Bahri, \& Prasetyo, 2020).

Desa Maredan Barat juga memiliki kawasan pantai yang belum dapat dimanfaatkan secara optimal. Kawasan pantai ini seharusnya dapat dimanfaatkan, diantaranya sebagai tambahan lapangan kerja yang akan bermuara pada peningkatan ekonomi masyarakat. Tentu saja hal ini hanya dapat dilakukan melalui peningkatan sumber daya manusia melalui pendidikan, penyuluhan dan pelatihan (Rusliadi dkk, 2018). Alternatif solusi untuk menyelesaikan permasalahan-permasalahan yang dihadapi masyarakat desa Maredan Barat adalah dengan memberikan pelatihan dan pendampingan pengembangan literasi., khususnya literasi baca tulis, literasi teknologi informasi dan komunikasi (TIK) dan literasi keuangan.

\section{METODE PENERAPAN}

Pelaksanaan kegiatan tahun pertama pembangunan Kampung Literasi dimulai pada bulan Juli sampai November 2020 dengan melibatkan 8 orang dosen FKIP Universitas Riau yang memiliki dari berbagai bidang ilmu, 10 orang mahasiswa KKN, 6 orang mahasiswa PLP. Pelaksanaan dimulai dengan melakukan survei dan mengadakan pertemuan antara tim kegiatan pengabdian kepada masyarakat ini dengan kepala desa dan perangkatnya serta pemuka masyarakat. Pada pertemuan tersebut disepakati bahwa kegiatan membangun Kampung Literasi akan dimulai dengan dan menyediakan sarana pemantik literasi masyarakat melalui penyediaan sebuah taman bacaan yang merupakan bagian dari Kampung Literasi serta membangun persepsi positif masyarakat terhadap Kampung Literasi. 
Penyediaan Taman Bacaan Masyarakat (TBM) dimulai dengan pengadaan tempat/ ruangan. Tempat yang disediakan kepala desa lokasinya adalah didepan kantor kepala desa. Awalnya, ruangan ini tidak berfungsi, namun kemudian direnovasi supaya dapat difungsikan. Sedangkan untuk membangun persepsi positif masyarakat terhadap Kampung Literasi, terlebih dahulu perlu ketahui dulu persepsi awal masyarakat dan pengetahuan mereka tentang Kampung Literasi. Untuk itu Tim Pengabdian mengembangkan sebuah angket yang terdiri dari 24 butir pertanyaan. Angket ini diberikan kepada 56 orang responden yang dipilih secara proporsional random samping. Responden ini tersiri dari terdiri dari 29 laki-laki dan 27 orang perempuan yang kesehariannya berpfofesi sebagai wirausaha/pedagang, petani, pelajar dan PNS.

\section{HASIL DAN KETERCAPAIAN SASARAN}

Adapun hasil dan ketercapaian program yang telah dilaksanakan adalah:

1) Pengembangan Taman Bacaan Masyarakat (TBM). Untuk tahap awal, Tim Pengabdian menyumbangkan 350 buah buku dari berbagai bidang ilmu dan tingkatan. Kemudian pihak kepala desa memberi pula 90 buah buku sebagai tambahan. Disamping itu Tim Pengabdian juga menymbangkan sebuah Personal Computer (PC) dan printer untuk mendukung kegiatan administrasi. Karena letaknya yang strategis, di depan kantor kepala desa, aktifitas TBM selalu mendapat pengawasan dari kepala desa dan dijadikan tempat untuk belajar dan diskusi siswa diluar jam kegiatan pembelajaran. Pemanfaat TBM ini sebagagian besar adalah para siswa yang mendiskusikan materi-materi pelajarannya bersama mahasiswa yang sedang mengikuti KKN dan PLP. Kedepan, TBM ini akan ditingkatkan menjadi sebuah Perpustakaan Desa. Kegiatan ini juga dimaksudkan sebagai upaya memasyarakatkan kebiasaan membaca.

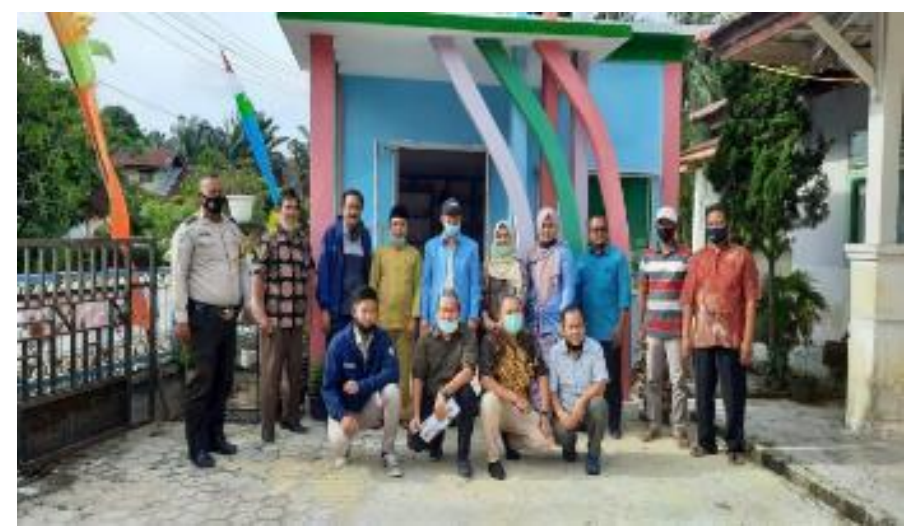

Gambar 1: Tim dosen dan perangkat desa di depan TBM

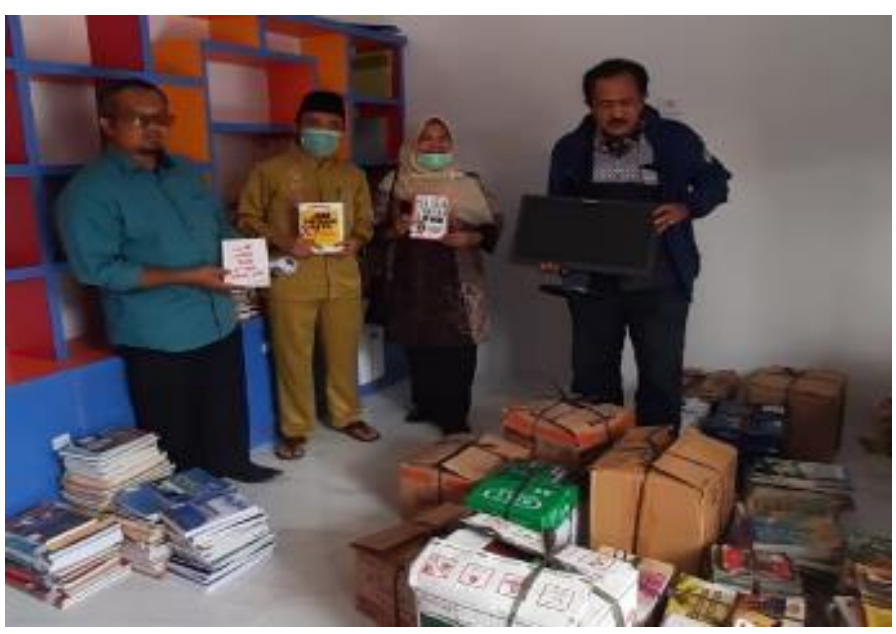

Gambar 2: Penyerahan buku dan PC kepada kepala desa 
2) Mahasiswa yang terlibat sebagai pelaksana Tim Pengabdian ini diberikan pengetahuan oleh tim dosen tentang pelaksanaan kegiatan pembelajaran daring. Berbekal pengetahuan tersebut, mahasiswa juga ‘menularkan' pengetahuan tersebut kepada guru dan siswa di desa Maredan Barat.

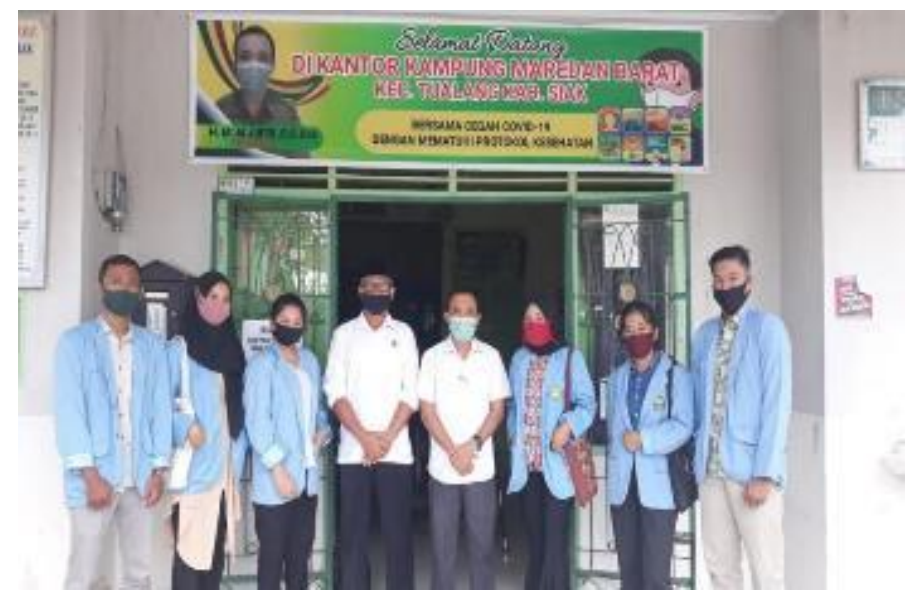

Gambar 3: Sebagian mahasiswa yang terlibat

3) Mahasiswa anggota Tim Pengabdian juga memberikan pembimbingan dalam belajar kepada para siswa sebagai upaya mengurangi beban dan kesulitan orang tua untuk mengajar anaknya selama masa pembelajaran daring disebabkan pandemi Covid-19. Kegiatan ini sangat membantu siswasiswa dalam memahami tugas yang diberikan oleh guru. Kegiatan ternyata ini sangat diminati oleh siswa karena di TBM juga tersedia banyak buku yang bisa dijadikan sebagai referensi. Awalnya buku-buku yang hanya dimaksudkan untuk memperlancar siswa dalam membaca, ternyata dapat dijadikan referensi dan bahan diskusi.

4) Memberikan pelayanan konsultasi dalam membimbing anak belajar bagi orang tua. Pelayanan ini lebih bersifat memberi bantuan bagi orang tua bagaimana menggunakan perangkat TIK dalam belajar. Banyak orang tua yang belum memahami tentang penggunaan komputer/ smartphone dan aplikasi-aplikasinya dalam membimbing anak belajar.

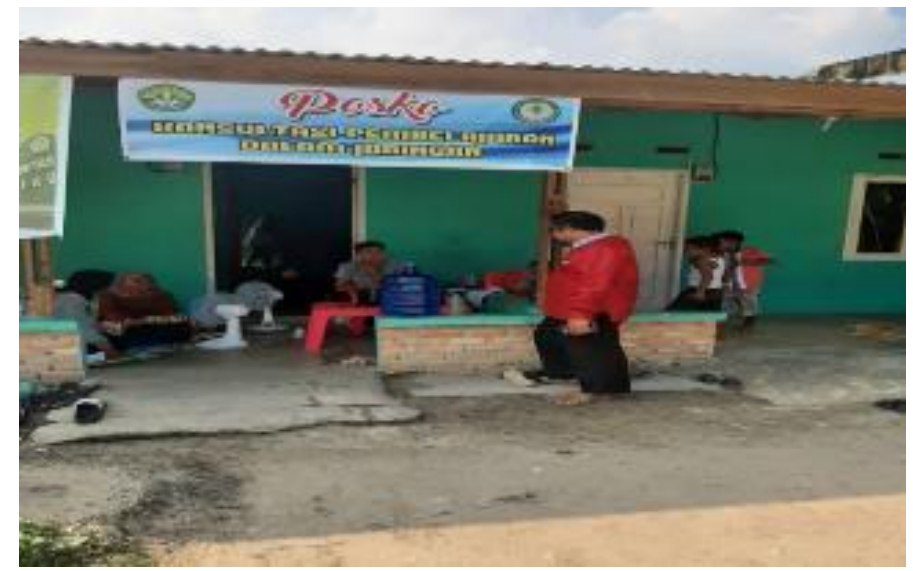

Gambar 4. Posko Konsultasi

5) Selanjutnya Tim Pengabdian menjalin kerja sama dengan berbagai pihak seperti Dinas Pendidikan Kabupaten Siak dan SMA Cendana, Mandau - Duri. Dari kerja sama tersebut telah didapatkan donasi-donasi berupa buku-buku. Pada ahirnya mahasiswa Tim Pengabdian membuka 'posko' donasi buku bacaan. Sampai saat ini telah terkumpul 613 eksemplar buku yang berasal dari sumbangan sebagai hasil dari kerja sama yang dilakukan. 

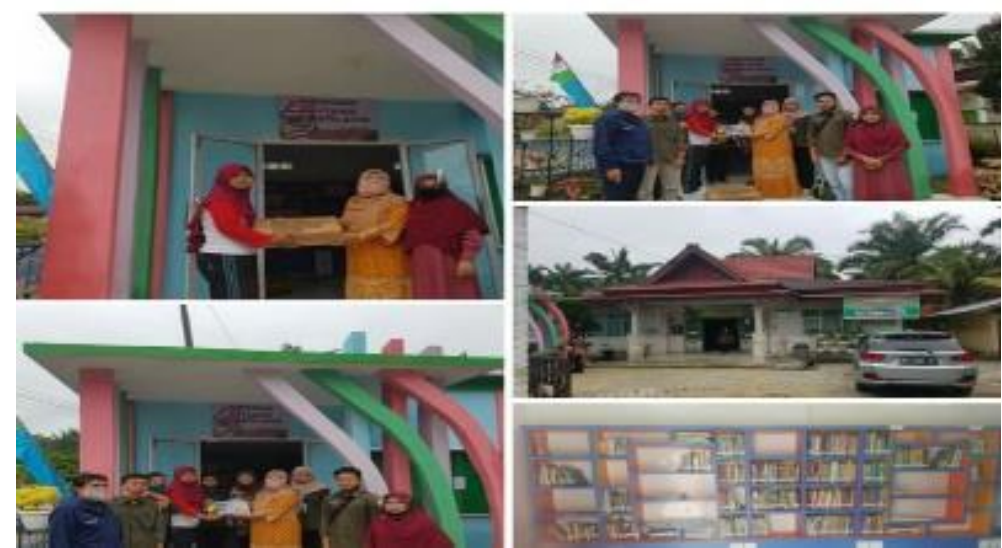

Gambar 5. Penyerahan Buku-buku dari SMA Cendana, Mandau - Duri

6) Melihat besarnya animo masyarakat terhadap TBM yang ada, Tim Pengabdi dan kepala desa serta perangkatnya terus melengkapi TBM dengan berbagai sarana-sarana pendukung seperti lemari/rak buku, meja baca, kursi, perlengkapan administrasi, dan lainnya di lokasi TBM.

7) Sampai saat ini kegiatan pengelolaan buku-buku yang ada masih dilaksanakan oleh mahasiswamahasiswa yang tergabung dalam Tim Pengabdian. Mulai dari menyusun, melakukan pendataan, membuat katalog hingga membuat panduan pengelolaan. Untuk kedepannya, Tim Pengabdi melatih dan melibatkan seorang petugas, warga desa yang nantinya akan melanjutkan pengelolaan TBM secara berkelanjutan.

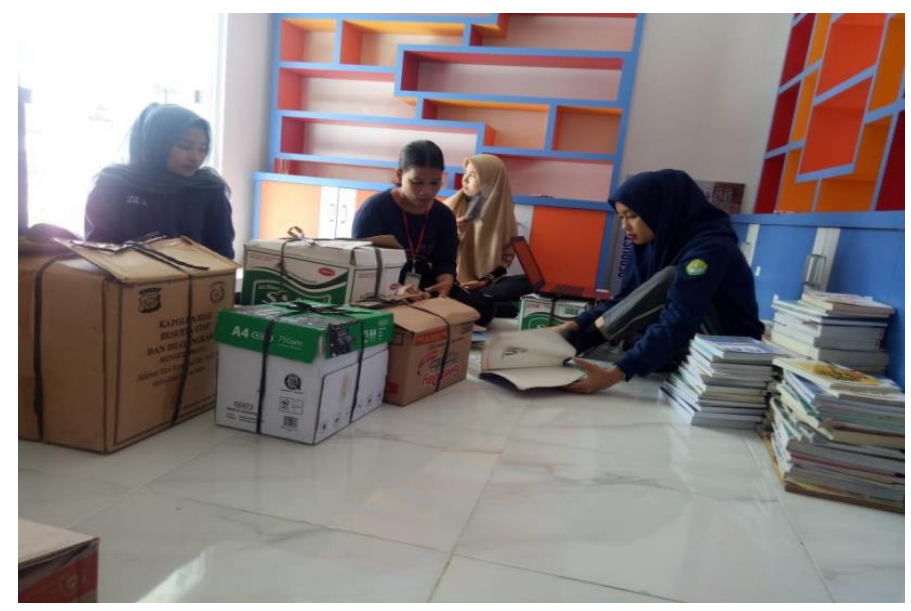

Gambar 6. Para Mahasiswa Terus Membenahi TBM

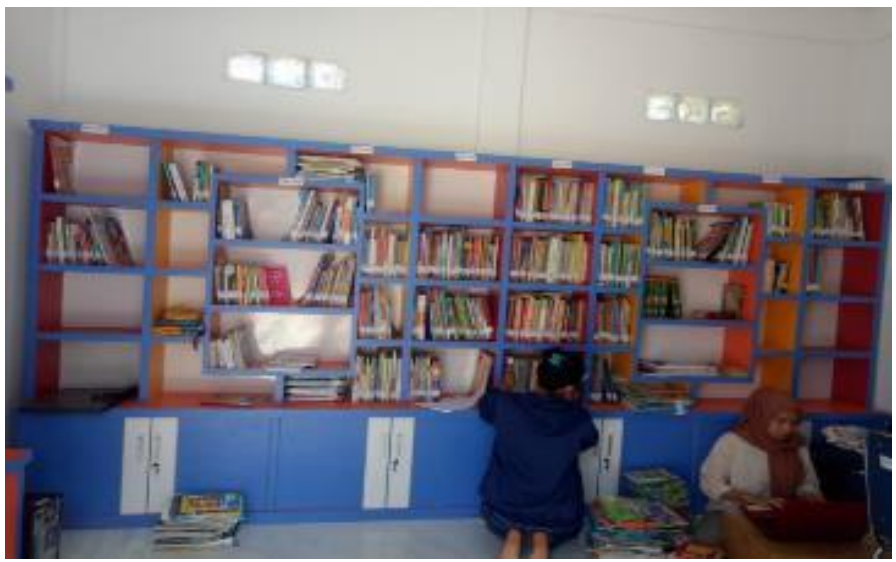

Gambar 7. Koleksi Buku-buku Terus Bertambah 
8) Bersempena dengan memperingati kegiatan 'Bulan Bahasa', Tim Pengabdian juga mengadakan berbagai lomba terkait Literasi Budaya dan Kewarganegaraan seperti: Lomba bermain kelereng, setatak, menggambar, mewarnai, baca puisi dan permainan rakyat lainnya. Upaya ini dilakukan sebagai bagian untuk mengajak anak-anak mengunjungi TBM karena lokasi pelaksanaan berbagai lomba tersebut adalah di halaman TBM dan kantor kepala desa.

Dari gambaran diatas, secara umum kegiatan pengembangan Kampung Literasi yang dilaksanakan sudah memenuhi harapan dari Tim Pengabdi walaupun disana-sini masih ditemukan berbagai kendala yang pada umumnya disebapkan adanya pandemi Covid-19.

\section{Persepsi masyarakat}

Untuk mengetahui tingkat keberhasilan pelaksanaan Kampung Literasi di desa Maredan Barat Kecamatan Tualang Kabupaten Siak, Tim Pengabdian telah mempersiapkan angket. Angket ini juga dimaksudkan untuk mengetahui persepsi masyarakat terhadap pelaksanaan kegiatan ini. Indikator persepsi masyarakat adalah tanggapan, pandangan dan penilaian mereka terhadap kegiatan yang dilaksanakan.

Hasil analisis angket memperlihatkan bahwa $45 \%$ dari responden telah memahami tentang Kampung Literasi. Walaupun angka ini terlihat kecil, namun dapat memberi kemudahan untuk pengembangan Kampung Literasi kedepannya. Masyarakat mempunyai keinginan untuk bersama-sama mengembangkan kampung literasi, meskipun sosialisasi terkait keberadaan kampung literasi masih dirasa kurang.

Pengetahuan masyarakat tentang keberadaan Taman Bacaan Masyarakat di dekat kantor kepala desa sudah cukup besar, mencapai angka $80 \%$. Hal ini menunjukkan bahwa masyarakat memiliki perhatian terhadap perkembangan kantor desa terutama dengan adanya TBM. Akan tetapi hanya $60 \%$ dari responden yang mengatakan pernah mendengar adanya sosialaisai tentang TBM di kantor desa. Hal yang mengejutkan adalah, semua responden setuju bahwa Kampung Literasi umumnya dan TBM khususnya akan memberikan dampak positif bagi kehidupan warga. Hal ini juga di tunjukkan dengan adanya persetujuan mereka terhadap tujuan Kampung Literasi.

Sebesar $60 \%$ dari responden mengatakan bahwa tujuan yang hendak dicapai oleh Kampung Literasi bukanlah hal yang tidak masuk akal. Hal ini sesuai dengan salah satu fungsi perpustakaan, yakni untuk menambah luas cakrawala mereka (Pandapotan, 2019). Seiring dengan hal tersebut semua responden berkeinginan untuk mensukseskan Kampung Literasi. Jika dilihat dari pendapat responden tentang pengelolaan TBM, ternyata $35 \%$ mengatakan bahwa pengelolaan TBM belum sesuai dengan harapan. Hal ini disebapkan karena waktu pelayanan yang mereka harapkan belum sesuai dengan keinginan. Penilaian responden tentang buku-buku yang ada di TBM berada pada kategori sangat baik (91\%), namun masih tetap diperlukan tambahan-tambahan, buku, khususnya buku-buku tentang keterampilan.

Dari persepsi masyarakat berdasarkan angket terlihat bahwa kegiatan Kampung Literasi sudah sesuai dengan kondisi masyarakat Desa Maredan Barat Kecamatan Tualang Kabupaten Siak. Apalagi masyarakat juga berkeinginan untuk bersama-sama membangun Kampung Literasi. Peran serta dan dukungan masyarakat dalam membangun Kampung Literasi amat diperlukan (Kementerian Pendidikan dan Kebudayaan, 2017).

\section{KESIMPULAN}

Secara umum kegiatan-kegiatan program pembangunan Kampung Literasi sudah berjalan dengan baik dengan adanya dukungan penuh dari kepala desa dan perangkatnya. Kegiatan-kegiatan yang dilaksanakan dapat membuka wawasan masyarakat tentang pentingnya keberadaan dan pengelolaan TBM yang baik sebagai dasar pengembangan Kampung Liteasi. Kedepannya TBM akan dijadikan sebuah perpustakaan desa yang menjadi pusat kegiatan untuk bersama-sama membangun desa melalui Kampung Literasi. Sosialisasi yang masih kurang hanyalah disebapkan karena adanya social distancing dan physical distancing karena adanya pandemi Covid-19.

\section{UCAPAN TERIMA KASIH}

Terima kasih kami ucapkan kepada pimpinan LPPM Universitas Riau yang telah memfasilitasi terlaksananya kegiatan ini. Ucapan terima kasih juga kami sampaikan kepada Kepala Desa Maredan Barat Kecamatan Tualang Kabupaten Siak dan perangkatnya yang telah bersedia menjadi mitra untuk bersama-sama membangun desa. 


\section{DAFTAR PUSTAKA}

Bahri, \& Prasetyo, W. 2020. Pengentasan kemiskinan melalui pemberdayaan wirausaha dan program life skill untuk meningkatkan produktivitas kelompok UPPKS Kalipakem Baru. Riau Journal of Empowerment, 3(1), 27-37. https://doi.org/10.31258/raje.3.1.27-37

Hayati, N., \& Suryono, Y. 2015. Evaluasi Keberhasilan Program Taman Bacaan Masyarakat Dalam Meningkatkan Minat Baca Masyarakat Di Daerah Istimewa Yogyakarta. Jurnal Pendidikan dan Pemberdayaan Masyarakat, 2(2), 175-191.

Hidayah, L., Widodo, G. S., \& Sueb. 2019 Revitalisasi Partisipasi Masyarakat Dalam Gerakan Literasi Nasional: Studi Pada Program Kampung Literasi. Jurnal Bidang Pendidikan Dasar (JBPD), 3(1), 87-98.

Kementerian Pendidikan dan Kebudayaan. 2017. Panduan Penyelenggaraan Kampung Literasi. Jakarta.

Pandapotan, S. 2019. Pengembangan model kampung literasi untuk meningkatkan motivasi pendidikan dan minat membaca masyarakat desa kolam kab. Deli serdang. Seminar Nasional Pengabdian Kepada Masyarakat Universitas Terbuka, (pp. 315-326). Indonesia.

Purwanti, A., Ispriyarso, B., \& Wijaningsih, D. 2018. Strategising Local Regulations on Women's Representation in Village Policymaking as a Realisation of Sustainable Development Goals: A Study on Semarang Regency. Journal of Social Studies Education Research, 9 (4), 319-333.

Rusliadi, I. Putra, M. Fauzi, N.A. Pamukas, dan H. Masjudi. 2018. Pengembangan mata pencaharian alternatif bagi nelayan melalui kegiatan budidaya ikan dengan teknologi bioflok di Kampung Sungai Kayu Ara. Riau Journal of Empowerment 1(2): 61-65. https://doi.org/10.31258/raje.1.2.8

Syahza, A., D. Bakce, and B. Asmit. 2018. Increasing the awareness of palm oil plantation replanting through farmers training. Riau Journal of Empowerment, 1 (1), 1-9. https://doi.org/10.31258/raje.1.1.1 